Pylyp Prystavka ${ }^{1}$, Olha Cholyshkina ${ }^{2}$

${ }^{1}$ National Aviation University, Kyiv, Ukraine

${ }^{2}$ Interregional Academy of personnel management, Kyiv, Ukraine

\title{
COMPARATIVE ANALYSIS OF DIFFERENTIAL INVARIANTS BASED ON THE SPLINE MODEL FOR VARIOUS IMAGE DISTORTION
}

\begin{abstract}
In the task of finding the features of digital images, it is relevant to determine solutions that provide high processing speed. In the article experimental studies of the application of differential invariants based on the partial image model as a linear combination of B-splines that are close to the average interpolation. Such a model retains the properties of the Gaussian model in the frequency domain, but has less computational complexity, which allows us to better investigate its asymptotic properties and the properties of the corresponding partial derivatives used in the construction of differential invariants. The issue of differences in gradient magnitude, Lapsasian, Hessian determinant, and curvature of the scaling curve during image processing was studied, and the masks of low-frequency filters and operator masks were minimized based on differences of smoothing operators. It has been experimentally proved that smoothing of digital images and reduction of their linear sizes allows to formalize the process of feature selection on the basis of analysis of probability distributions of introduced differential invariants. The suggested approach may be recommended when searching for similar objects containing different images. The approach considered in the work has a low computational complexity, which makes it possible to recommend it for use in systems with a low computation speed, in particular for systems operating on single-board computers.
\end{abstract}

Keywords: image model, B-spline; differentiation operators; differential invariants distributions; invariant values.

\section{Introduction}

Today, the generally accepted approach to searching for local features of digital images (DI) is to use differential invariants [1] based on continuous models, most often using private derivatives of the first and second order two-dimensional Gauss function [2-7]. The only drawback when using the kerosene image model can be considered relative computational complexity, but for special cases, this warning is not significant, because when processing the DI, discrete convolutions with pre-calculated masks are used.

By a model alternative on the basis of Gaussian there is a spline-model [8] as linear combination of $B$ splines, that is near to interpolation in middle [9]. Such a model retains almost all the properties of the Gaussian model in the frequency domain, however, it has a much lower computational complexity, which makes it possible to better investigate its asymptotic properties and the properties of the corresponding partial derivatives [1012], which are used in constructing differential invariants. As researches of authors showed [12], even limit amount of operators on the basis of spline model, allows effectively to decide the task of search steady to the turns and down-scalings of features of DI. This approach also has an advantage over patented methods, because the model and operators based on it are publicly available. Therefore, for the further development of the method of using the spline model DI it is important to study its application in different types of distortions, which is why this work is devoted.

Analysis of publications and statement of the research problem. Let [8] be in a continuous twodimensional image model $p(t, q)$ as a function of the pulse call uses the model:।

$$
\begin{gathered}
S_{r, 0}(p, t, q)= \\
=\sum_{i \in Z} \sum_{j \in Z} p_{i, j} B_{r, h_{t}}\left(t-i h_{t}\right) B_{r, h_{q}}\left(q-j h_{q}\right), r=2,3, \ldots .
\end{gathered}
$$

where $B_{r, h}(\cdot)-B$-spline of order $\mathrm{r}$ defined by [9] on a uniform partition of the real axis with a step $h$.

Then, due to the explicit form of the model (1), it is not difficult to obtain both the explicit form of its partial derivatives and their discrete analogues suitable for processing digital images. From private derivatives

$$
\left(\begin{array}{c}
S_{r, 0}^{\prime}(p, t, q)_{t}, S_{r, 0}^{\prime}(p, t, q)_{q}, S_{r, 0}^{\prime \prime}(p, t, q)_{t t}, \\
S_{r, 0}^{\prime \prime}(p, t, q)_{q q}, S_{r, 0}^{\prime \prime}(p, t, q)_{t q}
\end{array}\right),
$$

for each of the models (1) of order $r=2,3, \ldots$ four differential invariants with respect to local rotations can be constructed - gradient magnitude $\left|\nabla S_{r, 0}\right|$, Laplacian $\nabla^{2} S_{r, 0}$, Hessian determinant $\operatorname{det} \mathrm{H}_{r, 0}$ and the curvature of the scaling curve $\tilde{k}_{r, 0}$ (up to the notation of operators of different order):

$$
\begin{gathered}
|\nabla S|=S_{t}^{\prime 2}+S_{q}^{\prime 2}, \\
\nabla^{2} S=S_{t t}^{\prime \prime}+S_{q q}^{\prime \prime}, \\
\operatorname{det} \mathrm{H}=S_{t t}^{\prime \prime} S_{q q}^{\prime \prime}-S_{t q}^{\prime \prime 2}, \\
\tilde{k}=S_{t}^{\prime 2} S_{q q}^{\prime \prime}+S_{q}^{\prime 2} S_{t t}^{\prime \prime}-2 S_{t}^{\prime} S_{q}^{\prime} S_{t q}^{\prime \prime},
\end{gathered}
$$

At different $r=2,3, \ldots$ the authors obtain explicit types of partial derivatives of model (1). So, for work with DI at $r=3$ discrete analogs $S_{3,0}^{\prime}(p, t, q)_{t}$, $S_{3,0}^{\prime}(p, t, q)_{q}$ considering $h_{t}=h_{q}=1$, can be filed as follows [11]:

$$
S_{3,0, l}^{\prime}=\sum_{i i=i-1}^{i+1} \sum_{j=i-1}^{j+1} \gamma_{l, i i-i, j j-j}^{\prime} \cdot p_{i i, j j},
$$

where

$$
l=\{t, q\}
$$




$$
\gamma_{t}^{\prime}=\frac{1}{12}\left(\begin{array}{ccc}
-1 & -4 & -1 \\
0 & 0 & 0 \\
1 & 4 & 1
\end{array}\right) ; \gamma_{q}^{\prime}=\frac{1}{12}\left(\begin{array}{ccc}
-1 & 0 & 1 \\
-4 & 0 & 4 \\
-1 & 0 & 1
\end{array}\right) .
$$

Discrete convolutions of second-order differentiation operators $r=3$ such:

$$
S_{3,0, l}^{\prime \prime}=\sum_{i i=i-1}^{i+1} \sum_{j=i-1}^{j+1} \gamma_{l, i i-i, j j-j}^{\prime \prime} \cdot p_{i i, j j},
$$

where $l=\{t t, q q, t q\} ; \gamma_{t t}^{\prime \prime}=\frac{1}{6}\left(\begin{array}{ccc}1 & 4 & 1 \\ -2 & -8 & -2 \\ 1 & 4 & 1\end{array}\right)$;

$$
\gamma_{q q}^{\prime \prime}=\frac{1}{6}\left(\begin{array}{ccc}
1 & -2 & 1 \\
4 & -8 & 4 \\
1 & -2 & 1
\end{array}\right) ; \gamma_{t q}^{\prime \prime}=\frac{1}{4}\left(\begin{array}{ccc}
1 & 0 & -1 \\
0 & 0 & 0 \\
-1 & 0 & 1
\end{array}\right) .
$$

Similarly, first-order and second-order partial derivatives are obtained for higher-order.

In the author's work [10] the method of determining the features on the basis of operators (2) (5), obtained with the help of expressions like (6), (7), is widely described. In contrast to the well-known method SIFT [13] and its like, it is proposed to use the distribution of differential invariants, in particular to identify which of them are present on «tails» distributions when selecting features. This approach has been analysed in more detail in the work [12], but such research can be continued as described in this publication.

According to [12], the possibility of using invariants (2) - (5) to identify objects in the production of aerial photography was considered (Fig. 1).

It was proposed to use a linear operator to determine the detectors to the reference image (Fig. 1). $\operatorname{Delta}\left(p^{i, j}\right)$ in the form of a discrete convolution of the sequence $\left\{p_{i, j}\right\}_{i, j \in \mathbb{Z}}$ :

$$
\begin{gathered}
d_{-} p_{i, j}=\operatorname{Delta}\left(p^{i, j}\right)= \\
=\sum_{i i=i-3}^{i+3} \sum_{j j=j-3}^{j+3} \delta L_{i i-i, j j-j} p_{i i, j j}, \quad i, j \in \mathbb{Z},
\end{gathered}
$$

where $\left\{d_{-} p_{i, j}\right\}_{i, j \in \mathbb{Z}}$ - a newly formed sequence for finding special points; $\delta L$ - symmetric matrix dimensional of (7x7);

$$
\begin{gathered}
\delta L=\frac{1}{21233664} \times \\
\times\left(\begin{array}{ccccc}
0,01 & 7,22 & 105,43 & 235,48 & \ldots \\
7,22 & 3738,28 & 37781,9 & 72695,6 & \ldots \\
105,43 & 37781,9 & 114745,93 & -47679,32 & \ldots \\
235,48 & 72695,6 & -47679,32 & -878100,32 & \ldots \\
\vdots & \vdots & \vdots & \vdots & \ddots
\end{array}\right) .
\end{gathered}
$$

This operator is based on model (1), a discrete analogue of the function of the difference of Gaussian folding functions of two near scales, divided by constant factors with the original image, which is used in the construction of the pyramid of images [14].

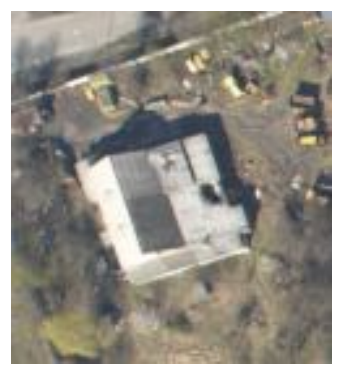

$\mathrm{a}$

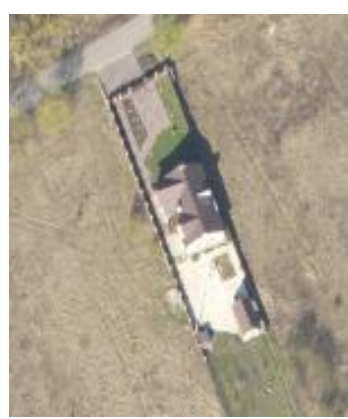

$\mathrm{c}$

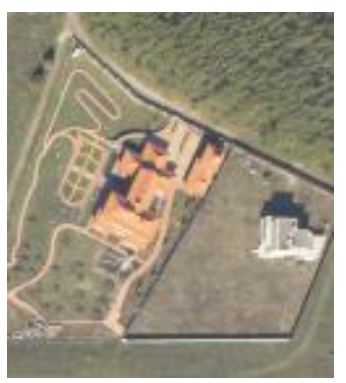

$\mathrm{t}$

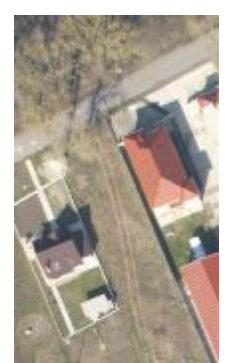

$\mathrm{b}$

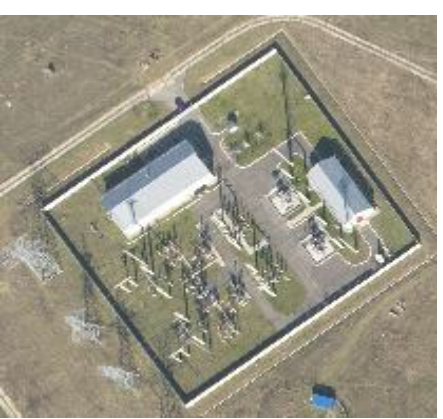

d

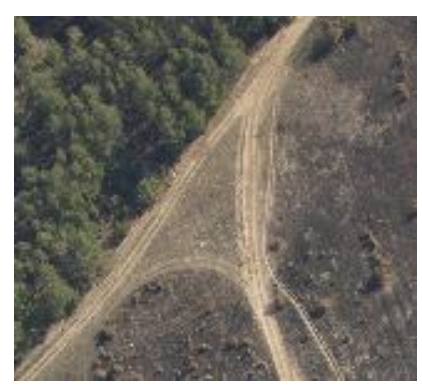

f
Fig. 1. Test examples of terrain elements according to aerial photography

In particular, the calculation of the convolution of the original image with Gaussian functions or other DI models, smoothing like (1), is necessary to describe features in the scale-position space. Such a convolution can be determined by simply subtracting Gaussian or spline images, in addition, such a difference gives a closed approximation of the scale-normalized Lapsassian.

After application (8) we form [12] a threedimensional array

$$
E x t=\left\{\left(\operatorname{ext}_{l}, i_{-} \text {pos }_{l}, j_{-} \text {pos }_{l}\right) ; l=\overline{1, M}\right\}
$$

scope $M$, that as $\operatorname{ext}_{l}, l=\overline{1, M}$ contains the value of the invariant calculated in the locations of local minima and $\operatorname{maxima}\left\{d_{-} p_{i, j}\right\}_{i, j \in \mathbb{Z}}:$ if

$$
d_{-} p_{i, j}=\max \left\{d_{-} p_{i i, j j} ; i i=\overline{i-1, i+1}, j j=\overline{j-1, j+1}\right\}
$$

or

$$
d_{-} p_{i, j}=\min \left\{d_{-} p_{i i, j j} ; i i=\overline{i-1, i+1}, j j=\overline{j-1, j+1}\right\},
$$

then $\quad i_{-} \operatorname{pos}_{l}=i, j_{-} \operatorname{pos}_{l}=j$. 
This approach to determining the location of DI features is not original - the SIFT method and many of its modifications for the same purpose use the abovementioned difference of DI convolutions with Gaussian, the analogue of which is expression (8).

Using the received locations of the local extrema were calculated ext $_{l}, l=\overline{1, M}$ - value (2)-(5) singular point detectors taking into account (6), (7) after collapsing derived spline masks with $\left\{d_{-} p_{i, j}\right\}_{i, j \in \mathbb{Z}}$. It is worth noting that the high saturation of singular points even for small fragments of images imposes the requirement to select those detector values corresponding to unlikely realizations on the tails of the distributions of operators (2) - (5). Therefore, it was proposed [12] to analyze the probability distribution of the array of values for the final selection of special points suitable for recognition $\left\{\operatorname{ext}_{l} ; l=\overline{1, M}\right\}$ specific detector and leave those that meet the conditions:

$$
\begin{gathered}
\operatorname{ext}_{l} \leq \operatorname{ext}_{\alpha_{1}}, l=\overline{1, M}, \text { ext }_{\alpha_{1}}=F^{-1}\left(\alpha_{1}\right) ; \\
\text { ext }_{l} \geq \text { ext }_{1-\alpha_{2}}, l=\overline{1, N}, \text { ext }_{1-\alpha_{2}}=F^{-1}\left(1-\alpha_{2}\right),
\end{gathered}
$$

where $F^{-1}(\bullet)$ - the inverse function of the probability distribution to the detector for a specific central zone by $\left\{e_{t} ; l=\overline{1, M}\right\} ; \quad$ ext $_{\alpha_{1}}, \quad$ ext $_{1-\alpha_{2}}$ - quantiles of such distribution on its tails at some rather small probabilities $\alpha_{1}$ and $\alpha_{2}$.

When analyzing the distributions of operators (2), (3) and (5), which have a distribution density function close to symmetric, which, for definiteness, can, for example, be set $\alpha_{1}=0,01$ and $\alpha_{2}=0,01$, what should be left for further analysis $2 \%$ from the number of special points. And for the distribution of the operator (4) worth taking value $\alpha_{1}$ less, and for the right tail $\alpha_{2}$ - more, for example, $\alpha_{1}=0,005$ and $\alpha_{2}=0,015$. In addition, the number of singular points in work [12] studied the effect of smoothing and reducing the linear dimensions of the DI . In particular, convolutions with symmetric masks were used to smooth the DI $(7 \times 7)$

$$
\begin{gathered}
\gamma^{(6)}=\frac{1}{21233664} \times \\
\times\left(\begin{array}{ccccc}
0,01 & 7,22 & 105,43 & 235,48 & \ldots \\
7,22 & 5212,84 & 76120,46 & 170016,56 & \ldots \\
105,43 & 76120,46 & 1111548,49 & 2482665,64 & \ldots \\
235,48 & 170016,56 & 2482665,64 & 5545083,04 & \ldots \\
\vdots & \vdots & \vdots & \vdots & \ddots
\end{array}\right) .
\end{gathered}
$$

What are obtained on the basis of the spline model (1) at $r=6$.

It was experimentally shown that the number of singular points on DI can be significantly reduced by smoothing and decreasing their linear dimensions. In this case, we obtain a mesh number of special points with detector distributions that differ from the distributions on the initial size DI only by the scale. Therefore, it can be stated that the definition of singular points is quite positively affected by both smoothing DI and reduction of their linear dimensions, because the number of points decreases, but the value of detectors correlates with those determined for the original image. With regard to the choice of a specific differential invariant for the determination of singular points, it is recommended to pay attention to the curvature of the scaling curve $\tilde{k}$ (5), after all, it is for this operator that the maximum growth rate of the detector distribution function can be observed near zero, and therefore the features that will be highlighted on the tails will be more "characteristic" and their number will be relatively smaller.

In general, given the low computational complexity, the considered approach can be used as a basis for information technology data processing, where the requirement for computational complexity is critical, for example when performing calculations on lowpower computers, such as those used for target load subsystems in reconnaissance drones. drone. However, further research requires a question similar to the analysis of the distributions of invariants (2) - (5) when they are applied directly to the image, and not after the convolution, which is determined by the operator (8) $\operatorname{Delta}\left(P_{I, J}\right)$. We aim to explore this issue in this work.

\section{Main material}

If the location of the feature is determined directly by the values $\left\{p_{i, j}\right\}_{i, j \in \mathbb{Z}}$, that is, formed (9), or an array of indexes $\left\{\left(i_{-}\right.\right.$pos $_{l}, j_{-}$pos $\left.\left._{l}\right) ; l=\overline{1, M}\right\}$, then consider in the graphs (Fig. 2) the distribution of the corresponding differential invariants calculated at these points for the array $\left\{p_{i, j}\right\}_{i, j \in \mathbb{Z}}$.

From the visual analysis of the given graphs it is possible to state their similarity with the abovementioned distributions presented in [12]. However, there are differences that are worth noting. The difference in scale along the abscissa axis is obvious. There is a difference in the growth rate of the gradient distribution function (2) and the behavior of the Lapsasian distribution near zero.

It will be useful to analyze the effect of the DI smoothing operation on the distribution of the calculated invariants. Without diminishing the generality, we present graphs of the distributions of invariants (2) - (5) on the example of smoothing one of the images.

After smoothing we have (Fig. 3): for the distribution of the operator (2) neither the scale nor the form of the distribution has practically changed; for others, there is a change in scale; for the distribution of the operator (3) - the shape of the distribution in the vicinity of the quantile 0.5 has changed significantly. The latter can be a characteristic feature of the procedure of smoothing the DI, so we give the distributions of this operator for other DI.

From the analysis of the graphs (Fig. 4) it is obvious that smoothing has a very significant effect on the distribution of lapsasian, which should be taken into account in subsequent studies. 

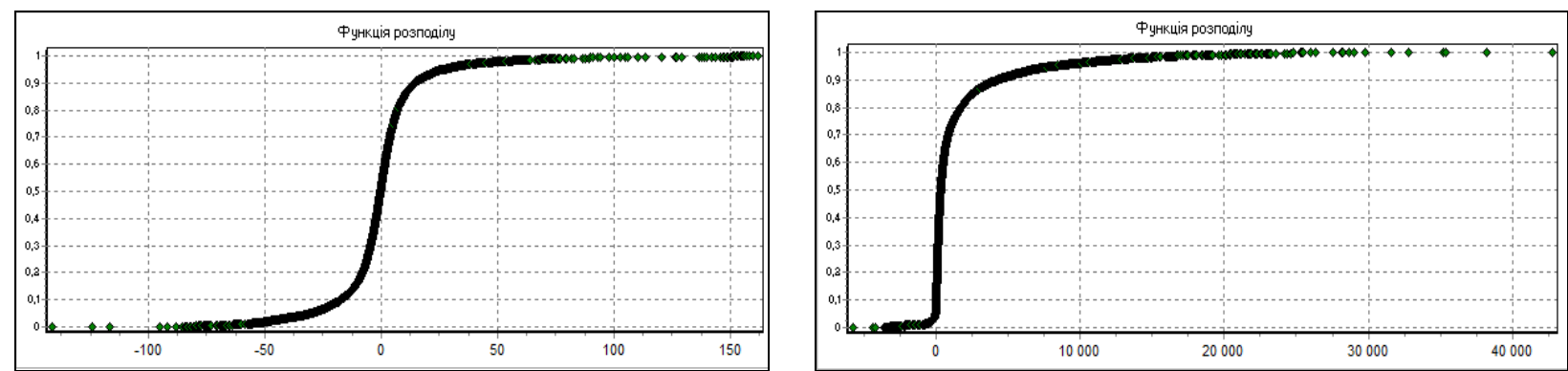

$\mathrm{a}$
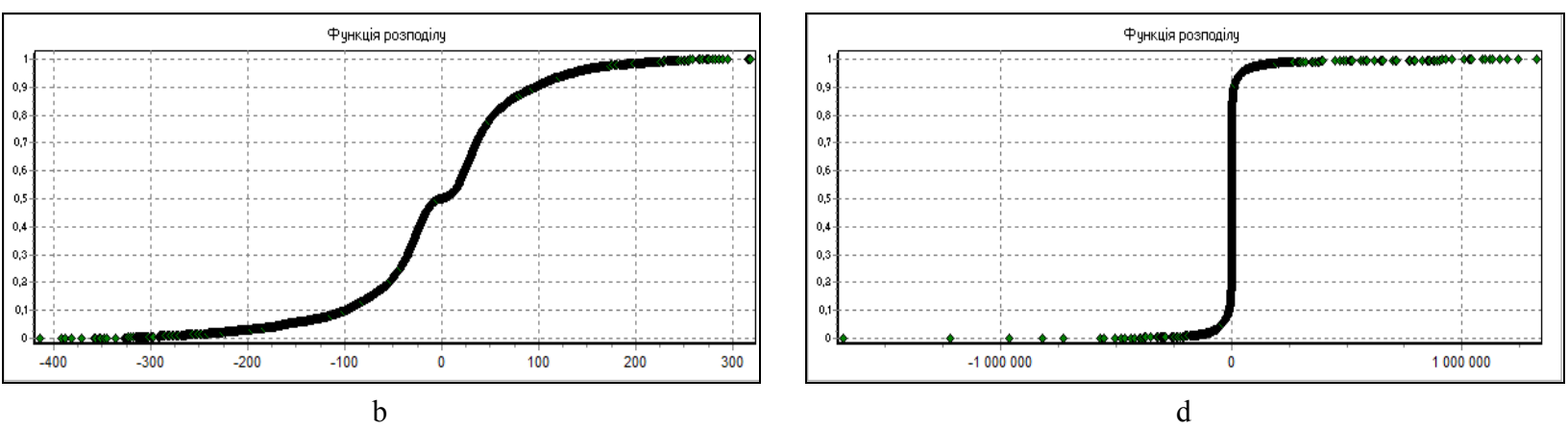

Fig. 2. Distributions of the operator (2) - (5) on the example of the image "g": a - (2), b - (3), c - (4), d - (5)
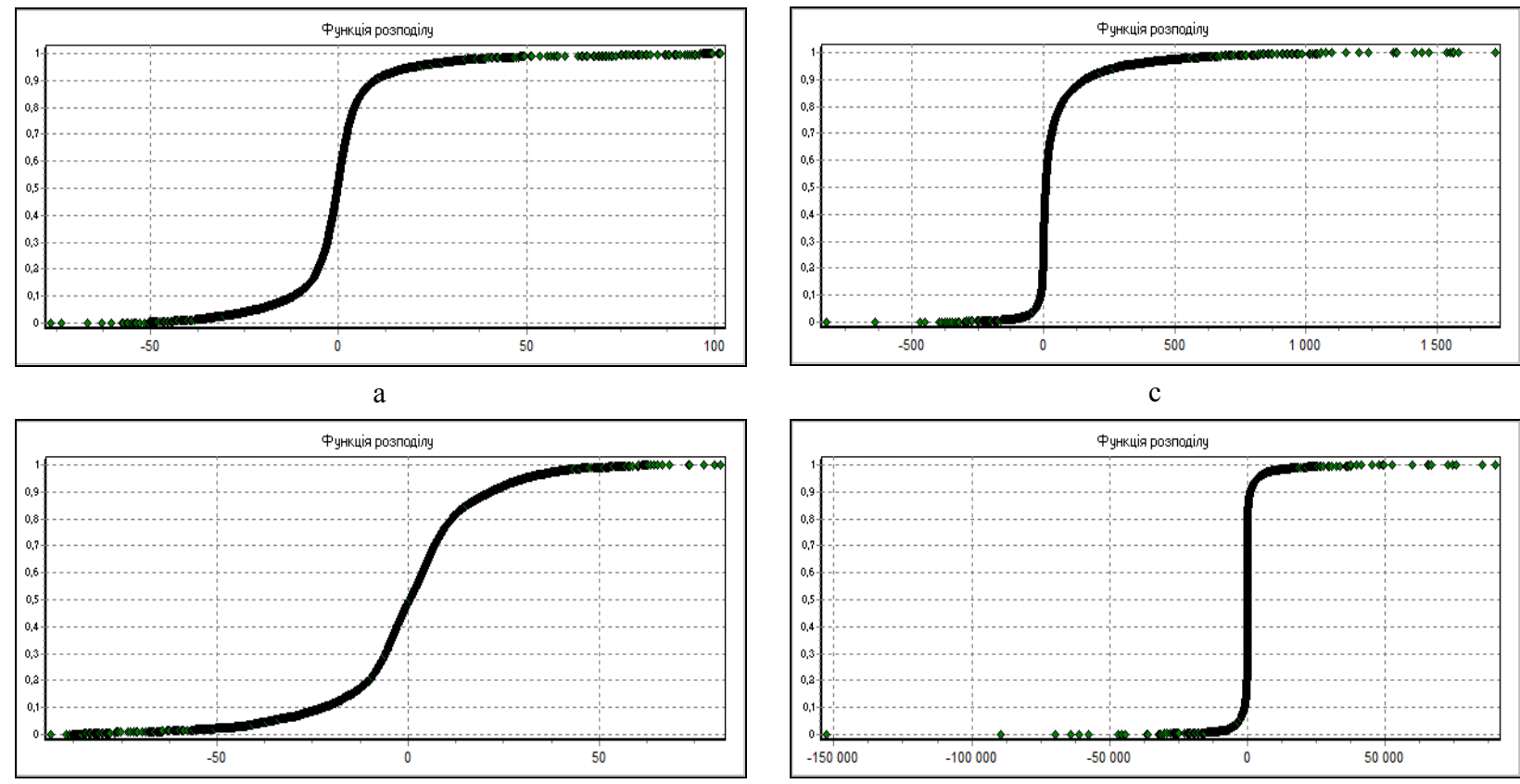

$\mathrm{b}$

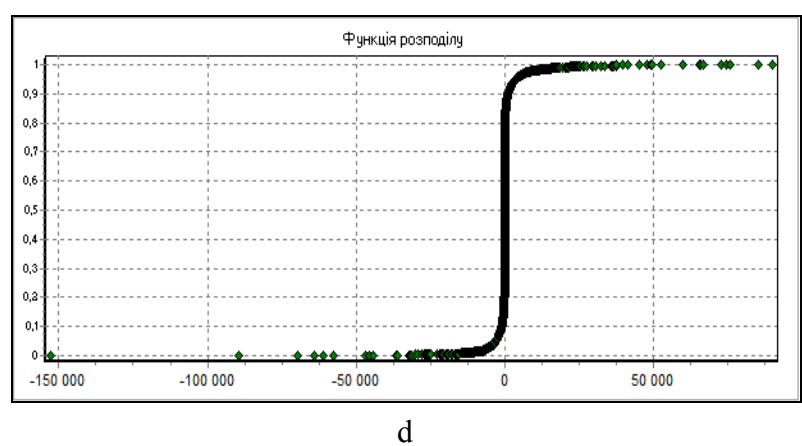

Fig. 3. Distributions of detectors after smoothing of the image "g" (fig. 1) operator with mask (12): $a$ - distribution of the operator (2); b- (3); c-(4); d-(5)

It is useful to study the correlation (Table 1) of differential invariants (2) - (5) for images before and after smoothing (at the same points).

Table 1 -Estimates of the linear correlation coefficient for the values of invariants that are calculated from the output DI and smoothed with a mask (12)

\begin{tabular}{|c|c|c|c|c|c|c|}
\hline & a & b & c & d & e & f \\
\hline$(3.2)$ & 0,968 & 0,964 & 0,949 & 0,927 & 0,947 & 0,89 \\
$(3.3)$ & 0,925 & 0,895 & 0,877 & 0,819 & 0,907 & 0,858 \\
$(3.4)$ & 0,737 & 0,562 & 0,63 & 0.463 & 0,595 & 0,52 \\
$(3.5)$ & 0,828 & 0,757 & 0,798 & 0,798 & 0,792 & 0,78 \\
\hline
\end{tabular}

When analyzing the data shown in the table (Table 1), attention is drawn to a significant relationship between the values of the Lapsasian and the gradient of the output and smoothed images and less correlation for the curvature and, especially, the Hessian determinant (4).

This may be due to the "heavier" tails of the last two distributions that appeared after smoothing. However, all the given correlation coefficients are significant and it can be argued that in further research, attention should be paid to the possibility of using exactly smoothed DI, because in this case, objectively more "persistent" features should be expected. 


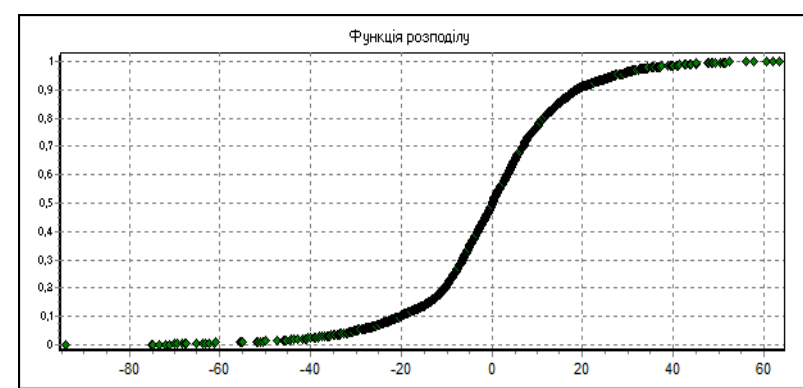

a

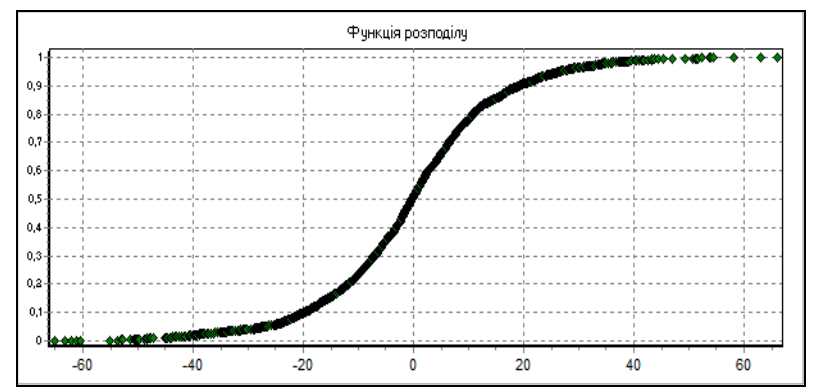

b

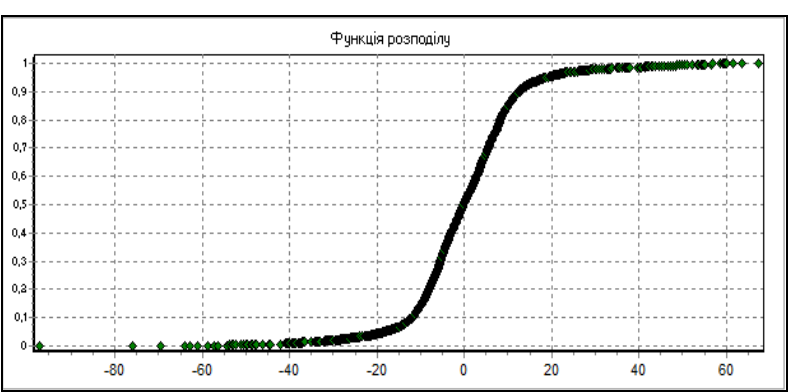

$\mathrm{c}$

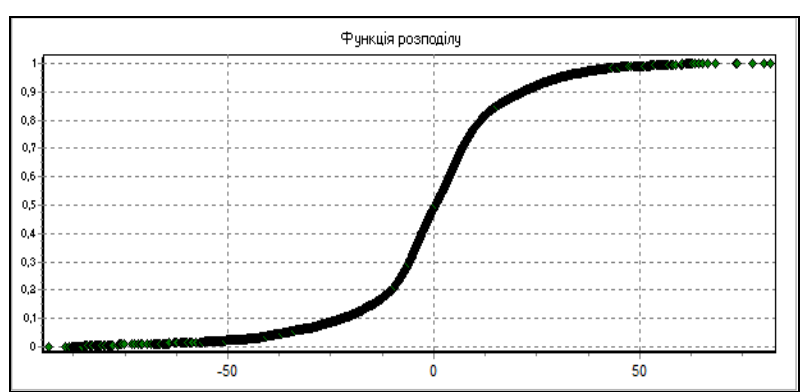

d
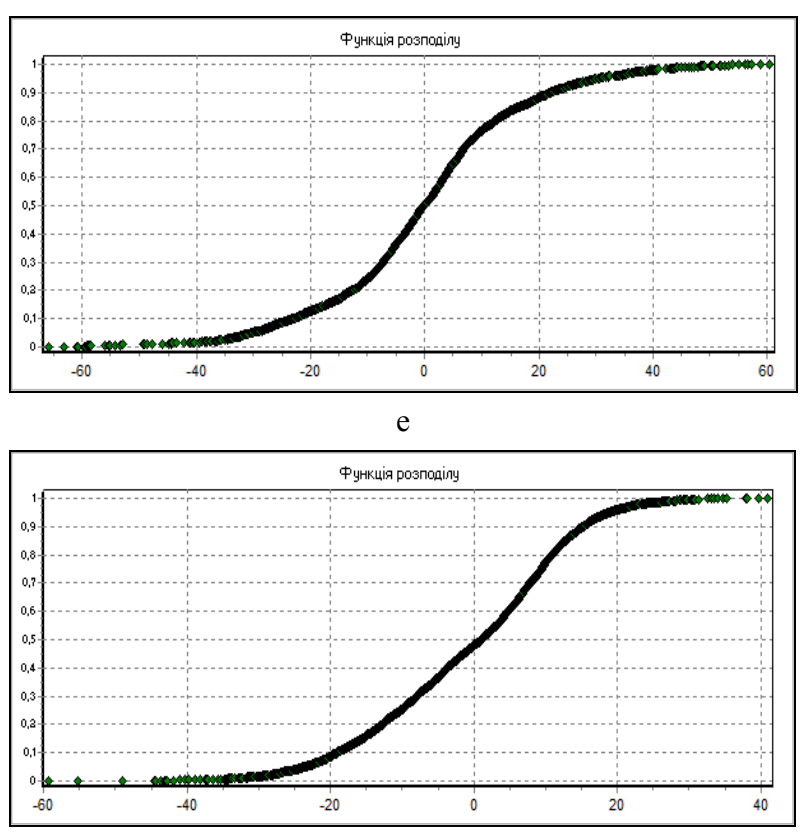

f

Fig. 4. Operator distributions (3.3) after DI smoothing

We will not bypass and analyze the correlation of differential invariants that are calculated for the original or smoothed DI and DI after the application of the operator $\operatorname{Delta}\left(P_{I, J}\right)$ (Table 2, 3).

When analyzing the tables (Tables 2 and 3), we first see the complete consistency of the values of the operator (3) - Lapsassian. The explanation is that the operator $\operatorname{Delta}\left(P_{I, J}\right)$ in fact, it is an approximation of the normalized. In addition, a high correlation is observed for the values of the invariant (4) in contrast to the gradient (2) and curvature (5). However, such values of the correlation of invariants (2) and (5) are also statistically significant.

The scaling operation (reduction with smoothing) shows (Table 4) that the correlation of the values of operators (2) and (5) increases significantly, which in itself may be useful to take into account in further studies the issue of selecting the positions of singular points. Finally, in this section, we give graphs of the distributions (Fig. 5) of the differential invariants calculated for the image " $\mathrm{d}$ " (Fig. 1) after reduction with smoothing and once again smoothing of the already reduced DI.

Table 2 - Correlation of invariant values calculated for the output DI and after application Delta( $\left(\boldsymbol{P}_{I, J}\right)$

\begin{tabular}{|c|c|c|c|c|c|c|}
\hline & a & b & c & d & e & f \\
\hline$(3.2)$ & $-0,798$ & $-0,852$ & $-0,847$ & $-0,889$ & $-0,882$ & $-0,828$ \\
$(3.3)$ & $-0,99$ & $-0,99$ & $-0,99$ & $-0,979$ & $-0,989$ & $-0,986$ \\
$(3.4)$ & 0,967 & 0,962 & 0,975 & 0,939 & 0,951 & 0,944 \\
$(3.5)$ & $-0,807$ & $-0,822$ & $-0,884$ & $-0,884$ & $-0,875$ & $-0,81$ \\
\hline
\end{tabular}

Table 3 - Correlation of invariant values calculated for smoothed DI with mask (12) and after application Delta $\left(P_{I, J}\right)$

\begin{tabular}{|c|c|c|c|c|c|c|}
\hline & $\mathbf{a}$ & $\mathbf{b}$ & $\mathbf{c}$ & $\mathbf{d}$ & $\mathbf{e}$ & $\mathbf{f}$ \\
\hline$(3.2)$ & $-0,613$ & $-0,561$ & $-0,567$ & $-0,714$ & $-0,631$ & $-0,52$ \\
$(3.3)$ & $-0,977$ & $-0,976$ & $-0,976$ & $-0,984$ & $-0,983$ & $-0,981$ \\
$(3.4)$ & 0,912 & 0,888 & 0,926 & 0,952 & 0,907 & 0,91 \\
$(3.5)$ & $-0,556$ & $-0,574$ & $-0,591$ & $-0,746$ & $-0,583$ & $-0,509$ \\
\hline
\end{tabular}


Table 4 - Correlation of invariant values

\begin{tabular}{|c|c|c|c|c|c|c|}
\hline & $\mathbf{a}$ & $\mathbf{b}$ & $\mathbf{c}$ & $\mathbf{d}$ & $\mathbf{e}$ & $\mathbf{f}$ \\
\hline$(3.2)$ & $-0,818$ & $-0,798$ & $-0,792$ & $-0,855$ & $-0,832$ & $-0,668$ \\
$(3.3)$ & $-0,988$ & $-0,991$ & $-0,992$ & $-0,989$ & $-0,991$ & $-0,988$ \\
$(3.4)$ & 0,962 & 0,973 & 0,974 & 0,957 & 0,96 & 0,935 \\
$(3.5)$ & $-0,786$ & $-0,871$ & $-0,877$ & $-0,876$ & $-0,875$ & $-0,686$ \\
\hline
\end{tabular}

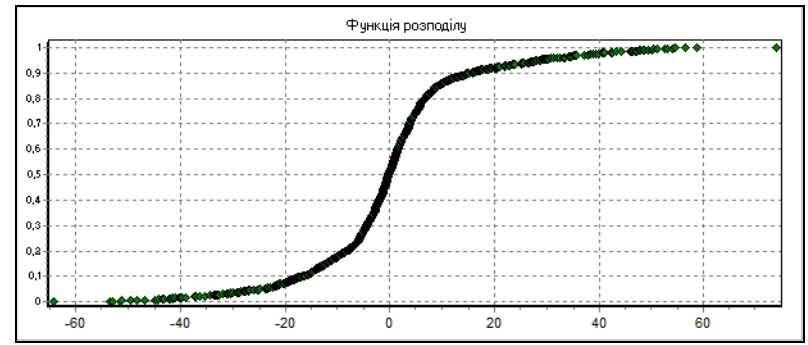

a

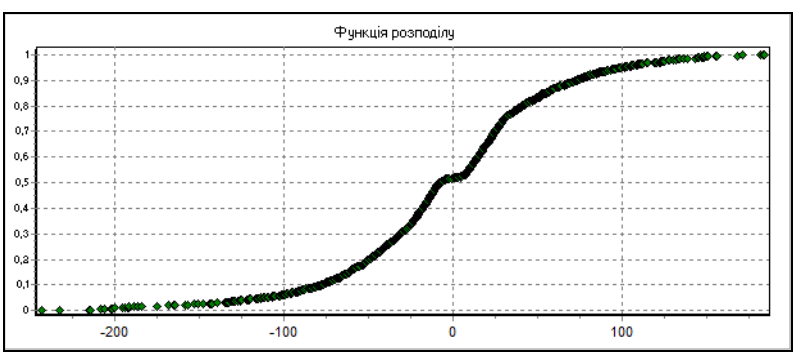

b

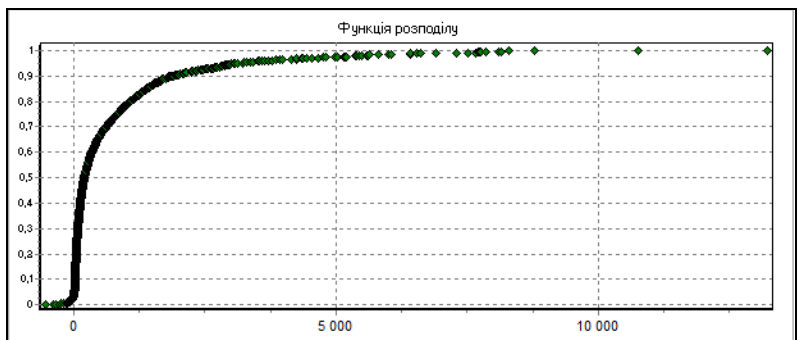

c

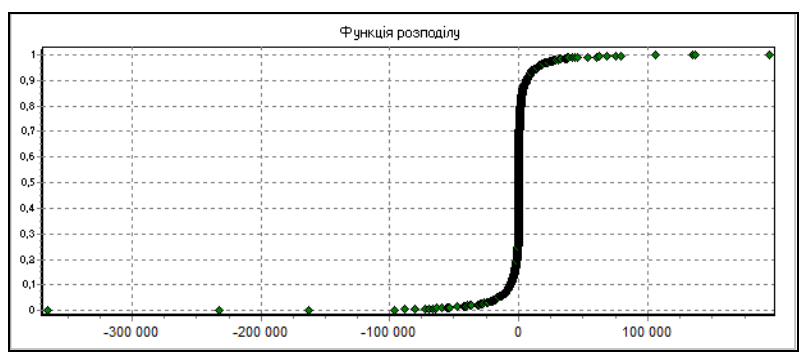

d

Fig. 5. Distributions of image detectors «d» (Fig. 3) after reduction with smoothing by the operator (12) and again applying after that smoothing with a mask (12): a - operator distribution (2); b - (3); c)- (4); d)- (5)

As we can see (Fig. 5), the tails of the distributions have become quite "heavy". Perhaps this fact can be useful, because it is on the tails of the distributions of invariants should expect the value of features (special points), the most "resistant" to various operations on DI - such as displacement, rotation, scaling, smoothing, and the like.

\section{Conclusions}

As a result of the conducted experimental researches it is established that application to initial DI of the operator (8) $\operatorname{Delta}\left(P_{I, J}\right)$ when finding singular points has no priority in comparison with the definition of features on the basis of differential invariants (2) (5) before the approach, was investigated in this work, namely - the calculation directly behind the raster. In both cases, the distributions of all invariants have a similar shape and, despite the different scales along the abscissa, there is a significant correlation of their values.

It was further confirmed that fewer features are significantly affected by DI smoothing and reduction of linear dimensions, with those remaining features located on the tails of differential invariants distributions, which allows you to formalize the selection process for further analysis and use in the task of searching for similar objects in photos. In contrast to the known ones, the considered approach has objectively less computational complexity, which allows us to recommend it for use in systems with low computing speed, in particular for systems running on single-board computers.

At further researches it is necessary yet to pay attention to the analysis of percent of coincidences site of feature for standard and control objects on the basis of offered approach.

\section{REFERENCES}

1. Kukharenko, B.G. (2011), “Algorithms of image analysis for determining local features and recognition of objects and panoramas", Information Technology, No. 7, Appendix, 32 p.

2. Sobel, I.E. (1970), Camera Models and Machine Perception, PhD Thesis, Stanford University, CA.

3. Canny, J. (1986), "A computational approach to edge detection", IEEE Transactions on Pattern Analysis and Machine Intelligence, Vol 8, No. 6, pp. 679-698.

4. Marr, D.C. and Hildreth, E. (1980), "Theory of edge detection", Proc. of the Royal Society of London, Vol. 207, Is. 1167, pp. 187-217, DOI: https://doi.org/10.1098/rspb.1980.0020

5. Schmid, C., Mohr, R. and Bauckhage, C. (2000), "Evaluation of interest point detectors", International Journal of Computer Vision, Vol. 37, No. 2, pp. 151-172.

6. Lindeberg, T. (2009), "Scale-space", Encyclopedia of Computer Science and Engineering, Hoboken, John Wiley and Sons, New Jersey, Vol. IV, pp. 2495 - 2504.

7. Koenderink, J.J. and van Dorn, A.J. (1992), “Generic neighborhood operators”, IEEE Transactions on Pattern Analysis and Machine Intelligence, Vol. 14, No. 6, pp. 597-605. 
8. Prystavka, P. and Ryabiy, M. (2012), "Model of realistic images based on two-dimensional splines close to interpolation on average", Science-intensive technologies, No. 3 (15), pp. 67-71.

9. Prystavka. P. (2004), Polynomial splines in data processing, Dnipropetrovsk Publishing House, Dnipropetrovsk, 236 p.

10. Prystavka, P. (2015), "Determining the features of images based on combinations of B-splines of the second order, close to the interpolation on average", Current issues of automation and information technology, Vol. 19, LIRA, pp. 67-77.

11. Prystavka, P., Tyvodar, O. and Martyuk, B. (2017), "Feature detection for realistic images based on b-splines of 3rd order related to interpolar on average", Proceedings of the National Aviation University, No. 2 (71), pp. 76-83.

12. Lowe, D.G. (1999), "Object recognition from local scale-invariant features", Proceedings of the International Conference on Computer Vision, Corfu, Greece, pp. 1150-1157.

13. Lowe, D.G. (2004), "Distinctive image features from scale-invariant keypoints", International Journal of Computer Vision, Vol. 60, No. 2, pp. 91-110.

14. Pawlak, Z (1991), Rough Sets - Theoretical Aspects of Reasoning about Data, Kluwer Academic Publ., Dordrecht, 246 p.

Надійшла (received) 11.08 .2020

Прийнята до друку (accepted for publication) 21.10.2020

ВідОмості ПРо АвтоРів / AвоUT THE AUTHORS

Приставка Пилип Олександрович - доктор технічних наук, професор, завідувач кафедри прикладної математики, Національний авіаційний університет, Київ, Україна;

Pylyp Prystavka - Doctor of Technical Sciences, Professor, Head of Applied Math Department, National Aviation University, Kyiv, Ukraine;

e-mail: chindakor37@gmail.com; ORCID ID: https://orcid.org/0000-0002-0360-2459

Чолишкіна Ольга Геннадіївна - кандидат технічних наук, декан факультету комп'ютерно-інформаційних технологій, Міжрегіональна Академія управління персоналом, Київ, Україна;

Olha Cholyshkina - PhD, Dean of Faculty computer-information technologies, Kyiv, Ukraine;

e-mail: greenhelga5@gmail.com; ORCID ID: https://orcid.org/0000-0002-0681-0413

Порівняльний аналіз диференціальних інваріантів на основі сплайн-моделі при різних спотвореннях зображень

П. О. Приставка, О. Г. Чолишкіна

Анотація. У завданнях пошуку особливостей цифрових зображень актуальним є визначення таких рішень, які забезпечують швидкодію при обробці. У статті проведено експериментальні дослідження застосування диференціальних інваріантів на основі часткових похідних моделі зображення, як лінійної комбінації В-сплайнів, що близькі до інтерполяційних у середньому. Така модель зберігає властивості гауссових моделі в частотній області, проте має меншу обчислювальну складність, що дозволяе краще дослідити асимптотичні властивості і властивості відповідний приватних похідних, що використовуються при побудові диференціальних варіантів. Вивчалось питання відмінностей результатів обрахунку магнітуди градієнта, лапсасіану, детермінанту гессіану та кривизни кривої масштабування при обробці зображень, що згортались 3 масками низькочастотних фільтрів та масок операторів, що побудовані на основі різниць операторів згладжування.. Експериментально підтверджено, що згладжування цифрових зображень і зменшення їх лінійних розмірів дозволяе формалізувати процес відбору особливостей на підставі аналізу розподілів ймовірностей введених диференціальних інваріантів. Запропонований підхід може бути рекомендований при пошуку схожих об'єктів, які містять різні зображення. Розглянутий в роботі підхід має низьку обчислювальну складність, що дозволяє рекомендувати його для використання в системах з низькою швидкістю обчислень, зокрема, для систем функціонують на одноплатних комп'ютерах.

Ключові слова: модель зображення, В-сплайни, оператори диференціювання, диференціальні інваріанти розподілу, інваріантні значення.

Сравнительный анализ дифференциальных инвариантов на основе сплайн-моделей при различных искажениях изображений

Ф. А. Приставка, О. Г. Челышкина

Аннотация. В задачах поиска особенностей цифровых изображений актуальным есть определение таких решений, которые обеспечивают быстродействие при обработке. В статье проведены экспериментальные исследования применения дифференциальных инвариантов на основе частных производных модели изображения, как линейной комбинации В-сплайнов, близких к интерполяционных в среднем. Такая модель сохраняет свойства гауссовой модели в частотной области, однако имеет меньшую вычислительную сложность, что позволяет лучше исследовать асимптотические свойства и свойства соответствующий частных производных, используемых при построении дифференциальных вариантов. Изучался вопрос различий результатов расчета магнитуды градиента, лапсасиану, детерминанту гессиан и кривизны кривой масштабирования при обработке изображений, сворачивались с масками низкочастотных фильтров и масок операторов, построенные на основе различий операторов сглаживания. Экспериментально подтверждено, что сглаживание цифровых изображений и уменьшение их линейных размеров позволяет формализовать процесс отбора особенностей на основании анализа распределений вероятностей введенных дифференциальных инвариантов. Предложенный подход может быть рекомендованный при поиске похожих объектов, которые содержат различные изображения. Рассмотренный в работе подход имеет низкую вычислительную сложность, что позволяет рекомендовать его для использования в системах с низкой скоростью вычислений, в частности, для систем, функционирующих на одноплатных компьютерах.

Ключевые слова: модель изображения, В-сплайны, операторы дифференцирования, дифференциальные инварианты распределения, инвариантные значения. 